\title{
Microbiological quality and characteristics of isolated Escherichia coli in irrigation water used in Napa cabbage cultivation
}

\author{
Bohyun Yun ${ }^{1}$ Y Younghoon $\mathrm{Kim}^{2} \cdot$ Nguyen Bao Hung ${ }^{1}$ • \\ Kyung-Hwan $\mathrm{Oh}^{3} \cdot$ Won-Il Kim ${ }^{1} \cdot$ Hyeonheui Ham ${ }^{1}$. \\ Hyun-Ju Kim $^{1} \cdot K^{\prime}$ youngyul Ryu ${ }^{1} \cdot$ Se-Ri Kim ${ }^{1}$ (I)
}

Received: 25 June 2018/ Accepted: 14 August 2018/Published online: 27 August 2018

(C) The Korean Society for Applied Biological Chemistry 2018

\begin{abstract}
To ensure the safety of Kimchi, the safety of Napa cabbage is the most important. Contaminated irrigation water can be a major cause of pathogens during growth of Napa cabbage. The purpose of this study was to investigate the microbial quality of irrigation water used in the cultivation of Napa cabbage. A total of 111 samples including surface water $(n=75)$ and groundwater $(n=36)$ collected from four different regions in Korea where Napa cabbage is intensively cultivated were analyzed for a fecal indicator (Escherichia coli) Moreover, 164 E. coli isolates from irrigation water were investigated for pathogenic characteristics including antibiotic resistance, pathogenic genes, serotype, and toxicity using Caenorhabditis elegans. E. coli was detected in $96 \%$ of surface water samples and $25 \%$ of groundwater samples. The level of $E$. coli in surface water $(0.2-3.2 \log$ MPN/100 mL) was higher than that in groundwater $(0-2.0 \log$ MPN/100 mL). When the 164 E. coli isolates were investigated concerning antibiotic resistance, resistance rates were $11.0 \%, 2.4 \%, 3.0 \%, 1.8 \%$, $2.4 \%, 4.3 \%$, and $3.0 \%$ for ampicillin, ampicillin/sulbactam, cefazolin, cefoxitin, gentamicin, levofloxacin, and trimethoprim/sulfamethoxazole, respectively. In addition,
\end{abstract}

Se-Ri Kim

seri81@korea.kr

1 Microbial Safety Team, Agro-Food Safety and Crop Protection Department, National Institution of Agricultural Sciences, Rural Development Administration, Wanju 55365, Korea

2 Department of Animal Science and Institute of Milk Genomics, Chonbuk National University, Jeonju 54896, Korea

3 Division of Enteric Bacterial Infectious, Center for Infectious Diseases, Korea National Institute of Health, Osong 28160, Korea
$10(6.1 \%)$ of the isolates were positive for the eaeA gene, indicative of enteropathogenic E. coli. Eight of these 10 isolates were obtained from the surface water of the mountainous region II and were toxic to $C$. elegans. The results indicate the need to manage the microbial risk of irrigation water to enhance the safety of cultivated Napa cabbage.

Keywords E. coli - Napa cabbage $\cdot$ Irrigation

\section{Introduction}

Kimchi was listed in the Codex Alimentarius in 2001 [1] and was ranked as one of the top four health foods in 2006 [2]. In Korea, the demand for Kimchi is increasing as the country's economy improves and group meals grow in popularity [3]. However, since Kimchi is a non-sterile, natural, fermented food that does not undergo sterilization during its manufacture, it is difficult to control contamination by foodborne bacteria unless the product is fully fermented [4]. Recent foodborne outbreaks associated with Kimchi have been reported [4]. To ensure the safety of Kimchi, the safety of Napa cabbage is paramount, since the cabbage is the main material of Kimchi. Potential sources of Napa cabbage contamination include substandard hygiene of personnel involved in cabbage harvest and processing, soil, animal feces, inadequately composted manure, and irrigation water [5, 6]. The latter is especially influential on the safety of Napa cabbage [7]. Irrigation water can be a major source of pathogens that persist during the growth of leafy vegetables [8-12]. Contaminated water was the reported source of intestinal pathogens in various recent crop-related outbreaks [13-16]. Several 
government regulatory authorities have proposed guidelines and standards for microbial water quality to minimize the associated risks of irrigation water [17-19]. However, in the agricultural water quality standard of Korea, microorganisms are not considered in the grade 4 environmental water quality standards [20]. It is necessary to establish microbial quality standards for irrigation water to ensure water safety, and hence crop safety.

In many countries, Escherichia coli is used as a water quality standard. Most of the E. coli strains used as water microbial quality standards are not harmful to humans. However, some strains can cause foodborne illness $[27,28]$. Foodborne outbreaks caused by Kimchi contaminated with pathogenic $E$. coli were reported in 2012. It is very important to evaluate whether $E$. coli isolated from agricultural water is likely to be a foodborne illness-causing strain. The determination of the virulence of $E$. coli often involves the detection of virulence genes using polymerase chain reaction (PCR). This approach is convenient to perform but is not always definitive, since the detection of even a pathogenic gene does not absolutely indicate pathogenicity [21, 22]. Therefore, pathogenic evaluation of $E$. coli requires in vivo toxicity evaluation as well the detection of pathogenic genes.

Animal models of toxicity provide critical information for assessing hazard and risk potential [23, 24]. However, many organizations, such as the Societies for Protection and Care of Animals, ethically oppose all forms of animal research [25]. Therefore, toxicity assessment using the Caenorhabditis elegans nematode has been introduced as an alternative to animal testing. The genetic complement of C. elegans is $60-80 \%$ similar to that of humans. However, advantageously, the unicellular $C$. elegans is less complex than multicellular mammalian organisms. C. elegans also has a short life cycle of about 3 days and has a non-hazardous biological system that can be easily maintained in the laboratory [26, 27]. In several studies, a correlation has been demonstrated between nematodes and pathogenic bacteria, and bacteria that are capable of killing mice $[28,29]$. Hence, $C$. elegans has been used extensively in biological studies as an in vivo surrogate host. In particular, C. elegans-pathogen models have been used to explore the pathogenesis of foodborne pathogens including pathogenic E. coli and Salmonella spp. [30].

This study was conducted to investigate the microbial contamination level of irrigation water in several major Napa cabbage cultivation regions in Korea. E. coli isolated from irrigation water was investigated for characteristics of pathogenicity, including the presence of pathogenic genes and $C$. elegans toxicity.

\section{Materials and methods}

\section{Investigation of microbiological quality}

Sampling for investigation of microbiological quality of irrigation water To investigate microbiological quality, a total of 111 water samples including surface water $(n=75)$ and groundwater $(n=36)$ were collected from four major Napa cabbage cultivation regions in Korea (Table 1). Sampling was conducted during harvest period of Napa cabbage. Regions I, II, and III were mountainous, while site IV was a flat region. Surface water samples were collected from a stream, valley, and pond near the cabbagegrowing farms. These samples were collected using a sterilized bucket and individually transferred to a sterilized screw-capped $2 \mathrm{~L}$ bottle. Groundwater samples were collected in $2 \mathrm{~L}$ sterilized bottles after the water was disembogued for $5 \mathrm{~min}$. All samples were transported to the laboratory in an icebox within $6 \mathrm{~h}$ of collection for microbiological analysis.

Escherichia coli in irrigation water Enzymatic analysis for E. coli was performed using the Colilert-18 system (IDEXX Laboratories, Westbrook, ME, USA). Briefly, $10 \mathrm{~mL}$ of each water sample was serially diluted with $90 \mathrm{~mL}$ of sterilized water. One capsule of Colilert-18 powder was added to each diluted sample and dissolved by shaking. Each sample was poured into a quanti-tray (IDEXX Laboratories). Each quanti-tray was sealed using a heat sealer (IDEXX Laboratories) and incubated at $37^{\circ} \mathrm{C}$ for $18 \mathrm{~h}$. The trays were then exposed to ultraviolet (UV) light $(365 \mathrm{~nm})$ in a UV light box, and fluorescence and color changes were observed. Yellow-colored wells and those that fluoresced were considered positive. The number of $E$. coli in each $100-\mathrm{mL}$ water sample was quantified using a most probable number (MPN) table provided by IDEXX.

Table 1 Irrigation water samples collected for testing microbial quality

\begin{tabular}{lllr}
\hline Region & Sampling period & Source of water & Number \\
\hline I & August & Surface water (stream, valley) & 24 \\
& & Groundwater & 6 \\
II & \multirow{2}{*}{ August } & Surface water (stream, valley) & 21 \\
& & Groundwater & 9 \\
III & \multirow{2}{*}{ October } & Surface water (stream, valley) & 15 \\
& & Groundwater & 12 \\
IV & \multirow{2}{*}{ November } & Surface water (ponds) & 15 \\
& & Groundwater & 9 \\
\multirow{2}{*}{ Total sample } & Surface water & 75 \\
& & Groundwater & 36 \\
\hline
\end{tabular}


For isolation of $E$. coli, aliquots $(0.1 \mathrm{~mL})$ from five suspected positive wells of each quanti-tray were acquired using a syringe (Korea Vaccine, Seoul, Korea). Each aliquot was inoculated in $10 \mathrm{~mL}$ of EC broth (Oxoid Ltd., Basingstoke, UK). After 18 -h incubation at $44{ }^{\circ} \mathrm{C}$, enriched cultures were streaked on EMB using a disposable loop. Plates were incubated at $37^{\circ} \mathrm{C}$ for $24 \mathrm{~h}$, and typical colonies were picked and identified using a VITEK system (bioMerieux, l'Etoile, France).

Statistical analysis Quantitative analysis data of E. coli in water collected from four regions were transformed to $\log$ MPN per $100 \mathrm{~mL}$. The data were analyzed by one-way analysis of variance (ANOVA) using SAS version 9.1 software (SAS Institute, Cary, NC, USA). All comparisons of means were performed using Duncan's multiple range test at an alpha $=0.05$.

\section{Characterization of $E$. coli isolated from water}

Bacterial isolates The total of 164 strains comprised 67 from region I, 49 from region II, 22 from region III, and 29 from region IV.

Analysis of antibiotic resistance of E. coli isolates Antibiotic resistance of the $E$. coli isolates was determined using the VITEK apparatus. Briefly, each isolated E. coli was cultured in nutrient agar (NA: Difco, Detroit, MI, USA) for $24 \mathrm{~h}$ at $37{ }^{\circ} \mathrm{C}$. The bacteria were adjusted to a McFarland standard turbidity of 0.6 using $0.45 \%$ sodium chloride solution, and $145 \mu \mathrm{L}$ of was diluted in $3 \mathrm{~mL}$ of $0.45 \%$ sodium chloride solution. Each diluted bacterial suspension was placed in the cassette of the VITEK apparatus along with and AST-N211 card (bioMerieux, France) coated with 17 antibiotics: ampicillin, amoxicillin/sulbactam, piperacillin/tazobactam, cefazolin, cefoxitin, cefotaxime, ceftazidime, cefepime, aztreonam, ertapenem, meropenem, amikacin, gentamicin, levofloxacin, tetracycline, and trimethoprim/sulfamethoxazole. Each cassette was put into the apparatus for analysis as detailed in the VITEK manual [31]. The results were determined according to the National Committee for Clinical and Laboratory Standards guideline [31]. E. coli ATCC 25922 and E. coli ATCC 35218 (American Type Culture Collection, Manassas, VA, USA) were used as the standards for antibiotic resistance.

Pathogenic genes of E. coli isolates from irrigation water were tested for the presence of eight pathogenic genes (LT, ST, VT1, VT2, bfpA, aggR, and ipaH) by polymerase chain reaction (PCR). The genomic DNA was isolated using a G-spin ${ }^{\mathrm{TM}}$ genomic DNA extraction kit (iNtRON Biotechnology, Sungnam, Korea) in accordance with the manufacturer's protocols. PCR was performed according to the manufacturer's method using the Pow$\operatorname{erChek}^{\mathrm{TM}}$ Diarrheal E. coli 4-plex Detection Kit I and II
(Kogenebiotech, Seoul, Korea). Briefly, $5 \mu \mathrm{L}$ of each DNA was added to $15 \mu \mathrm{L}$ of PCR premix that included reaction buffer, Taq polymerase, and primer. The thermocycler (Bio-Rad Laboratories, Hercules, CA, USA) conditions were: $94{ }^{\circ} \mathrm{C}$ for $10 \mathrm{~min} ; 30$ cycles at $94{ }^{\circ} \mathrm{C}$ for $30 \mathrm{~s}, 60{ }^{\circ} \mathrm{C}$ for $30 \mathrm{~s}$, and $72{ }^{\circ} \mathrm{C}$ for $30 \mathrm{~s}$; and extension at $72{ }^{\circ} \mathrm{C}$ for $10 \mathrm{~min}$. After PCR, amplification products were confirmed by $1.5 \%$ agarose gel electrophoresis.

Serotyping of E. coli O-antigens O Serotyping was used to identify isolates belonging to commercially defined $\mathrm{O}$ serogroups. For determination of O-antigens, the TSA bacterial culture was suspended in $3 \mathrm{~mL}$ of normal saline and heated to $100{ }^{\circ} \mathrm{C}$ for $1 \mathrm{~h}$. The boiled suspension was used as an antigenic mixture. One or two drops of specific O poly- or monovalent E. coli antisera (Joong Kyeom, Ansan, Korea) were mixed with the antigen preparation on a glass slide for $1 \mathrm{~min}$ and observed for agglutination.

In vivo evaluation of toxicity of E. coli Evaluation of the toxicity of $E$. coli possessing pathogenic genes was conducted using a $C$. elegans kill assay. C. elegans Bristol N2 wild-type strain (Caenorhabditis Genetics Center, University of Minnesota) was used. The assay was performed as previously described [32] with some modifications. Prior to the assay, the nematode worms were grown on agar plates of nematode growth medium (NGM) containing $3.0 \mathrm{~g}$ $\mathrm{NaCl}, 17.0 \mathrm{~g}$ agar, and $2.5 \mathrm{~g}$ peptone in $975 \mathrm{~mL} \mathrm{H}_{2} \mathrm{O}$. During growth at $25^{\circ} \mathrm{C}$, the nematodes were fed $E$. coli OP50 [33]. For the killing assay, 10 E. coli isolates possessing pathogenic genes were grown overnight $(18 \mathrm{~h})$ in the Luria-Bertani (LB) broth (Oxoid) at $37{ }^{\circ} \mathrm{C}$ at $180 \mathrm{rpm}$. Twenty microliter aliquots of each culture $\left(2 \times 10^{9} \mathrm{CFU} /\right.$ $\mathrm{mL}$ ) were spread on NGM agar plates. Worms were synchronized by hypochlorite bleaching, allowed to hatch overnight, and were subsequently cultured on NGM plates in the presence of E. coli OP50. Synchronized L1 larvae were transferred to NGM plates in the presence of $E$. coli OP50 and allowed to develop to L4 larvae. On day 3 after synchronization, 20 L4/young adult hermaphrodites were placed on each plate, incubated at $25^{\circ} \mathrm{C}$ for $45 \mathrm{~min}$, and transferred to a new plate every each $24 \mathrm{~h}$ to determine the survival rates of the original worms without the presence of progeny. The worms were considered dead when they did not respond to touching with a platinum wire pick. Each experimental condition was performed in triplicate. Nematode survival was examined using the Kaplan-Meier method, and differences were determined with the log-rank test (STATA6 software; STATA, College Station, TX, USA). 


\section{Results and discussion}

Recent cases of food poisoning caused by Kimchi in Korea have emphasized the safety of Kimchi [34]. Ensuring the safety of Kimchi depends critically on the safety of Napa cabbage, which is the main raw material of Kimchi $[4,34]$. Napa cabbage can be contaminated with foodborne pathogens through various routes, including irrigation water, soil, and inadequately composted manure. Irrigation water can be a major source of pathogens that persist for the duration of the growth of Napa cabbage. This study evaluated the microbial safety of irrigation water used for cabbage irrigation in four major cabbage-producing regions of Korea.

Escherichia coli was detected in $96 \%$ of the surface water samples and $25 \%$ of groundwater samples (Table 2). Surface water is more susceptible to microbial contamination than groundwater due to runoff, direct fecal sedimentation, and growth of bottom sediments [19, 35]. The level of E. coli in surface water and groundwater was 0.2-3.2 $\log$ MPN/100 mL and 0-2.0 $\log$ MPN/100 mL, respectively. The level of $E$. coli in surface waters from region I and III was significantly higher than those from region II and IV $(p<0.05)$. The difference in the level of $E$. coli among the regions was presumed to be affected by the locality and season. Region II was the highest altitude among the three mountainous areas, and sampling in region IV was conducted in the cold season of November. The number of $E$. coli from these two regions was relatively lower. Elsewhere, E. coli contamination of irrigation water used in lettuce cultivation in southern Brazil ranged from 2.1 to $5.4 \log$ CFU/100 mL [10], which was higher than in this study. In irrigation water in Spain and Bilge, E. coli contamination ranged from 1.0 to $1.5 \log \mathrm{CFU} / 100 \mathrm{~mL}$, which was lower than the present values $[8,15]$. The United States Food Safety Modernization Act (FSMA) requires that irrigation water that directly contacts the edible portion of the crop must have generic $E$. coli counts $\leq 126 \mathrm{CFU} / \mathrm{mL}$ [36]. Over half $(52.0 \%)$ of the surface water samples we sampled exceeded the FSMA safety level. However, no water quality standards for irrigation water have been legislated in Korea. Water quality standards for irrigation water are urgently needed in Korea.

This study investigated the characteristics of 164 E. coli isolated from irrigation water. The results of resistance to the 17 antibiotics by the 164 isolates are presented in Tables 3 and 4 . The overall resistance rate of E. coli was the highest in region I $(28.8 \%)$, followed by region III $(11 \%)$ and region IV $(3.7 \%)$. The antibiotic resistance rates were $11.0 \%, 2.4 \%, 3.0 \%, 1.8 \%, 2.4 \%, 4.3 \%$, and $3.0 \%$ for ampicillin, ampicillin/sulbactam, cefazolin, cefoxitin, gentamicin, levofloxacin, and trimethoprim/sulfamethoxazole, respectively. Of the $E$. coli isolated from surface water, $5.2 \%$ showed single resistance to ampicillin or cefazolin, and $8.4 \%$ showed resistance to multiple antibiotics. All multi-resistant strains were resistant to ampicillin. In addition, strains isolated from surface water of region I displayed resistance against five antibiotics (extended spectrum beta-lactam, ampicillin, gentamicin, levofloxacin, and trimethoprim/sulfamethoxazole). Moreover, one E. coli isolate from groundwater displayed resistance to three antibiotics (ampicillin, ampicillin/sulbactam, and trimethoprim/sulfamethoxazole). Sayah et al. [37] reported cephalothin resistance of $E$. coli isolated from the Red cedar watershed in the US. Chigor et al. [38] reported multi-drug resistance in E. coli and E. coli O157:H7 isolated from surface waters in Zaria, Nigeria. In another study, $73 \%$ of the $233 \mathrm{E}$. coli isolates from a region of water poisoning in the Dhaka area of Bangladesh displayed antibiotic resistance and $36 \%$ of the isolates displayed multi-drug resistance [39].

However, in this study, antibiotic resistance of E. coli isolates from irrigation water is relatively low compared to that isolated from livestock and aquatic production. Antibiotic resistance of E. coli isolated from livestock in Korea reportedly involves tetracycline, followed by ampicillin and streptomycin [40-42]. The highest rate of tetracycline resistance was also observed in E. coli isolated
Table 2 Contamination level and frequency of $E$. coli from irrigation water

\begin{tabular}{llrlll}
\hline Region & \multicolumn{2}{l}{ Surface water } & & Ground water \\
\cline { 2 - 3 } \cline { 5 - 6 } \cline { 5 - 6 } & Average $(\log$ MPN/100 ml) & Frequency $(\%)$ & & Average $(\log$ MPN/100 ml) & Frequency (\%) \\
\hline I & $2.9 \pm 0.5^{\mathrm{a}}$ & $100(24 / 24)$ & & $<0.1^{\mathrm{b}}$ & $17(1 / 6)$ \\
II & $1.7 \pm 0.7^{\mathrm{c}}$ & $90(19 / 21)$ & & $\mathrm{ND}^{\mathrm{b}}$ & $0(0 / 9)$ \\
III & $3.2 \pm 0.5^{\mathrm{a}}$ & $100(15 / 15)$ & & $2.0 \pm 1.1^{\mathrm{a}}$ & $58(7 / 12)$ \\
IV & $1.9 \pm 0.8^{\mathrm{b}}$ & $93(14 / 15)$ & & $<0.1^{\mathrm{b}}$ & $11(1 / 9)$ \\
Total & & $96(72 / 75)$ & & $25(9 / 36)$
\end{tabular}

$N D$ not detection

The data are present as the mean $\pm \mathrm{SD}$ of samples and the same letters are not significantly different among E. coli numbers in each region at $p<0.05$ according to Duncan's test 
Table 3 Analysis of antibiotics resistance of E. coli isolated from irrigation water according to regions

\begin{tabular}{lrlrrr}
\hline & \multicolumn{1}{l}{ I } & II & \multicolumn{1}{l}{ III } & \multicolumn{1}{l}{ IV } & \multicolumn{1}{c}{ Total } \\
\hline 1 drug & $9.1(6 / 66)$ & $0(0 / 49)$ & $11(2 / 22)$ & $0(0 / 27)$ & $4.9(8 / 164)$ \\
2 drugs & $10.6(7 / 66)$ & $0(0 / 49)$ & $0(0 / 22)$ & $0(0 / 27)$ & $4.3(7 / 164)$ \\
3 drugs & $3.0(2 / 66)$ & $0(0 / 49)$ & $0(0 / 22)$ & $3.7(1 / 27)$ & $1.8(3 / 164)$ \\
4 drugs & $4.5(3 / 66)$ & $0(0 / 49)$ & $0(0 / 22)$ & $0(0 / 27)$ & $1.8(3 / 164)$ \\
5 drugs & $1.5(1 / 66)$ & $0(0 / 49)$ & $0(0 / 22)$ & $0(0 / 27)$ & $0.6(1 / 164)$ \\
Total & $28.8(19 / 66)$ & $0(0 / 49)$ & $11(2 / 22)$ & $3.7(1 / 27)$ & $13.4(22 / 164)$ \\
\hline
\end{tabular}

Unit: \% (No. of antibiotics resistance of E. coli / No. of tested E. coli)

\begin{tabular}{|c|c|c|c|c|}
\hline & Antibiotics & Surface water & Ground water & Total \\
\hline \multirow[t]{2}{*}{1 drug } & Ampicillin & $4(6 / 155)$ & - & $4(6 / 164)$ \\
\hline & Cefazolin & $1(2 / 155)$ & - & $1(2 / 164)$ \\
\hline \multirow[t]{6}{*}{2 drugs } & Ampicillin & $1(2 / 155)$ & - & $1(2 / 164)$ \\
\hline & Ampicillin/sulbactam & & & \\
\hline & Ampicillin & $2(3 / 155)$ & - & $2(3 / 164)$ \\
\hline & Levofloxacin & & & \\
\hline & Cefazolin & $1(2 / 155)$ & - & $1(2 / 164)$ \\
\hline & Cefoxitin & & & \\
\hline \multirow[t]{9}{*}{3 drugs } & Ampicillin & $1(1 / 155)$ & - & $1(1 / 164)$ \\
\hline & Cefazolin & & & \\
\hline & Cefoxitin & & & \\
\hline & ESBL & $1(1 / 155)$ & - & $1(1 / 164)$ \\
\hline & Ampicillin & & & \\
\hline & Ampicillin/sulbactam & & & \\
\hline & Ampicillin & - & $11(1 / 9)$ & $1(1 / 164)$ \\
\hline & Ampicillin/sulbactam & & & \\
\hline & Trimethoprim/sulfamethoxazole & & & \\
\hline \multirow[t]{4}{*}{4 drugs } & Ampicillin & $2(3 / 155)$ & - & $2(3 / 164)$ \\
\hline & Gentamicin & & & \\
\hline & Levofloxacin & & & \\
\hline & Trimethoprim/sulfamethoxazole & & & \\
\hline \multirow[t]{5}{*}{5 drugs } & ESBL & $1(1 / 155)$ & - & $1(1 / 164)$ \\
\hline & Ampicillin & & & \\
\hline & Gentamicin & & & \\
\hline & Levofloxacin & & & \\
\hline & Trimethoprim/sulfamethoxazole & & & \\
\hline Total & & $13.5(21 / 155)$ & $11(1 / 9)$ & $13.4(22 / 164)$ \\
\hline
\end{tabular}

Unit: \% (No. of antibiotics resistance of E. coli / No. of tested E. coli)
Table 4 Analysis of antibiotics resistance of $E$. coli isolated from irrigation water according to water sources 
Table 5 Analysis of pathogenic gene and serotypes of E. coli isolated from irrigation water

\begin{tabular}{llll}
\hline Region & Pathogenic gene & Serotype & Isolates \\
\hline I & EPEC $(e a e A)$ & ONT & 1 \\
II & EPEC $(e a e A)$ & O121 & 3 \\
& EPEC $(e a e A)$ & O110 & 1 \\
& EPEC $(e a e A)$ & ONT & 1 \\
& EPEC $(e a e A)$ & O156 & 3 \\
& EPEC $(e a e A)$ & O171 & 1 \\
Total & & & $6.1 \%(10 / 164)$ \\
\hline
\end{tabular}

ONT o-nontypeable

Korea in 2012 was caused by enterotoxigenic E. coli (ETEC) and enteroaggregative E. coli (EAEC) isolated from Kimchi and a patient. In addition, ETEC was categorized as either the O99 or O120 serotype, and EAEC was belonged to the O120 serotype. Pulsed-field gel electrophoresis verified the close link between pathogenic E. coli from Kimchi and the patient. Thus, the E. coli that caused the 2012 outbreak was different from the E. coli isolated in this study. The eaeA-positive strains detected in this study seemingly pose less risk, but may be pathogenic. An ongoing study is investigating the specific molecular pathogenesis of $E$. coli isolated from the irrigation water mixed with groundwater and valley water. $C$. elegans was used to verify the virulence of isolated eaeA-positive bacteria. As shown in Fig. 1, E. coli strains isolated from the irrigation water mixed with groundwater and valley water of region II significantly decreased the survival of $C$. elegans compared with non-pathogenic $E$. coli OP50 $(p<0.05)$. Merkx-Jacques et al. [46] reported pathogenic gene-positive $E$. coli isolated from 143 water samples in the South Nation River in Canada that were tested for toxicity using $C$. elegans; $E$. coli-harboring toxic genes were pathogenic. However, some E. coli having a toxicity gene did not show any toxicity. These results suggest that the toxicity test of $C$. elegans can be evaluated indirectly for E. coli, which has the potential to be toxic for humans.

The irrigation water used in major Napa cabbage-producing regions was found to be inadequate in the case of mountainous areas. In addition, most of the pathogenic gene-positive strains of $E$. coli were detected in mountainous areas.

Several recent articles have reported that wildlife has been identified as a possible source of the waterborne pathogens, including E. coli. The access of wild animals to the mountainous area is easier than that to the plain area [47, 48]. Therefore, the load of microorganisms in agricultural water from mountainous regions is high. Moreover, there is increasing evidence of contamination of agricultural products due to irrigation water; however, there is insufficient information on the microbial quality of agricultural water [49]. Thus, the plans for improving the quality and safety of irrigation water for agricultural products should be urgently needed. First approach is to establish periodic monitoring system to identify sources of potential pathogens. Second approach is to develop and extend physical or chemical sterilization system that is easy
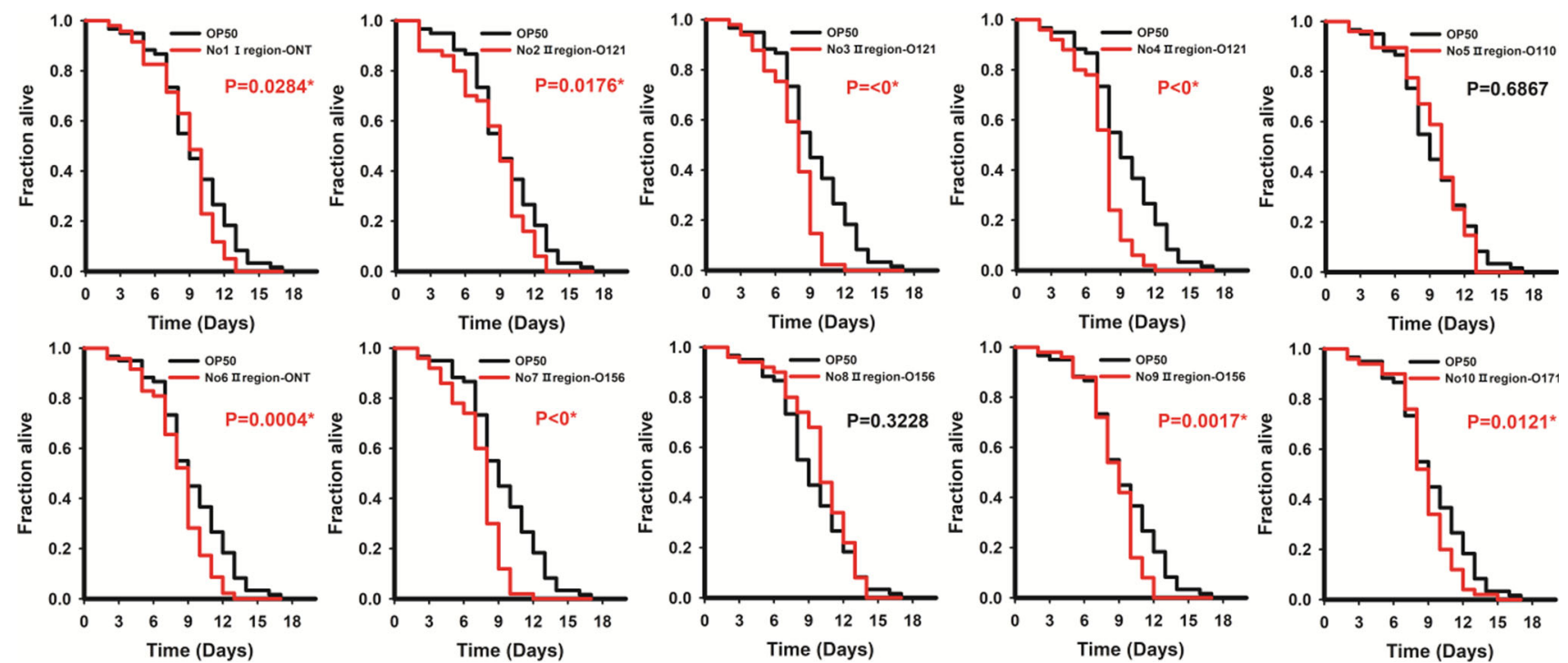

Fig. 1 Analysis of pathogenicity of $E$. coli isolated from irrigation water using nematode 
to apply in the field. Finally, criteria for the microbial quality of agricultural water should be established.

Acknowledgments This study was carried out with the support of the Research Program for Agricultural Science and Technology Development (Project No. PJ012009), and the National Institute of Agricultural Sciences, Rural Development Administration, Republic of Korea.

\section{References}

1. Codex (2001) Codex standard for kimchi (CODEX STAN 223-2001). FAO/WHO Joint Publications: Processed and Quick Frozen Fruits \& Vegetables. 5A

2. USA (2008) Health magazine. http://eating.health.com. Updated Feb 1

3. You JH, Shin MJ, Choi SK (2008) Importance and satisfaction with selection attributes when purchasing kimchi. J East Asian Soc Diet Life 18:624-632

4. Lee HW, Yoon SR, Kim SJ, Lee HM, Lee JY, Lee JH, Kim S, Ha JH (2017) Identification of microbial communities, with a focus on foodborne pathogens, during kimchi manufacturing process using culture-independent and-dependent analyses. LWT Food Sci Technol 81:153-159

5. Choi YD, Lee CW, Kim JS, Chung DH, Shim WB (2013) Investigation of hazards from onions and their cultivation areas to establish a good agricultural practices (GAP) model. Korean $\mathbf{J}$ Food Sci Technol 45:785-790

6. Beuchat LR, Farber JM, Garrett EH, Harris LJ, Parish ME, Suslow TV, Busta FF (2001) Standardization of a method to determine the efficacy of sanitizers in inactivating human pathogenic microorganisms on raw fruits and vegetables. J Food Prot 64:1079-1084

7. Uyttendaele M, Jaykus LA, Amoah P, Chiodini A, Cunliffe D, Jacxsens L, Holvoet K, Korsten L, Lau M, McClure P, Medema G, Sampers I, Jasti PR (2015) Microbial hazards in irrigation water: standards, norms, and testing to manage use of water in fresh produce primary production. Compr Rev Food Sci Food Saf $14: 336-356$

8. Castro-Ibáñez I, Gil M, Tudela J, Ivanek R, Allende A (2015) Assessment of microbial risk factors and impact of meteorological conditions during production of baby spinach in the Southeast of Spain. Food Microbiol 49:173-181

9. Ceuppens S, Hessel CT, de Quadros Rodrigues R, Bartz S, Tondo EC, Uyttendaele M (2014) Microbiological quality and safety assessment of lettuce production in Brazil. Int J Food Microbiol 181:67-76

10. Decol LT, Casarin LS, Hessel CT, Batista ACF, Allende A, Tondo EC (2017) Microbial quality of irrigation water used in leafy green production in Southern Brazil and its relationship with produce safety. Food Microbiol 65:105-113

11. Gelting RJ, Baloch MA, Zarate-Bermudez MA, Selman C (2011) Irrigation water issues potentially related to the 2006 multistate E. coli O157: H7 outbreak associated with spinach. Agric Water Manag 98:1395-1402

12. Park S, Navratil S, Gregory A, Bauer A, Srinath I, Jun M, Szonyi B, Nightingale K, Anciso J, Ivanek R (2013) Generic Escherichia coli contamination of spinach at the preharvest stage: effects of farm management and environmental factors. Appl Environ Microbiol 79:4347-4358

13. Cooley M, Carychao D, Crawford-Miksza L, Jay MT, Myers C, Rose C, Keys C, Farrar J, Mandrell RE (2007) Incidence and tracking of Escherichia coli O157: H7 in a major produce production region in California. PLoS ONE 2:e1159

14. Jay MT, Cooley M, Carychao D, Wiscomb GW, Sweitzer RA, Crawford-Miksza L, Farrar JA, Lau DK, O’Connell J, Millington A, Asmundson RV, Atwill ER, Mandrell RE (2007) Escherichia coli O157: H7 in feral swine near spinach fields and cattle, central California coast. Emerg Infect Dis 13:1908-1911

15. Holvoet K, Sampers I, Seynnaeve M, Uyttendaele M (2014) Relationships among hygiene indicators and enteric pathogens in irrigation water, soil and lettuce and the impact of climatic conditions on contamination in the lettuce primary production. Int J Food Microbiol 171:21-31

16. Zhang G, Ma L, Phelan VH, Doyle MP (2009) Efficacy of antimicrobial agents in lettuce leaf processing water for control of Escherichia coli O157: H7. J Food Prot 72:1392-1397

17. Edge T, El-Shaarawi A, Gannon V, Jokinen C, Kent R, Khan I, Koning W, Lapen D, Miller J, Neumann N, Phillips R, Robertson W, Schreier H, Scott A, Shtepani I, Topp E, Wilkes G, Bochove E (2012) Investigation of an Escherichia coli environmental benchmark for waterborne pathogens in agricultural watersheds in Canada. J Environ Qual 41:21-30

18. Organization WH (1989) Health guidelines for the use of wastewater in agriculture and aquaculture: report of a WHO scientific group (meeting held in Geneva from 18 to 23 November 1987)

19. Hong EM, Shelton D, Pachepsky YA, Nam WH, Coppock C, Muirhead R (2017) Modeling the interannual variability of microbial quality metrics of irrigation water in a Pennsylvania stream. J Environ Manage 187:253-264

20. An YJ, Lee WM, Yoon CG (2006) Evaluation of Korean water quality standards and suggestion of additional water parameters. Korean J Ecol Environ 39:285-295

21. Schierack P, Steinrück H, Kleta S, Vahjen W (2006) Virulence factor gene profiles of Escherichia coli isolates from clinically healthy pigs. Appl Environ Microbiol 72:6680-6686

22. Kim JY, Kim SH, Kwon NH, Bae WK, Lim JY, Koo HC, Kim JM, Noh KM, Hung WK, Park KT, Park YH (2005) Isolation and identification of Escherichia coli O157: H7 using different detection methods and molecular determination by multiplex PCR and RAPD. J Vet Sci 6:7-19

23. Wilson-Sanders SE (2011) Invertebrate models for biomedical research, testing, and education. ILAR J 52:126-152

24. Badyal DK, Desai C (2014) Animal use in pharmacology education and research: The changing scenario. Indian $\mathrm{J}$ Pharmacol 46:257-265

25. Richmond J (2002) Refinement, reduction, and replacement of animal use for regulatory testing: future improvements and implementation within the regulatory framework. ILAR J 43:S63-S68

26. Leung MC, Williams PL, Benedetto A, Au C, Helmcke KJ, Aschner M, Meyer JN (2008) Caenorhabditis elegans: an emerging model in biomedical and environmental toxicology. Toxicol Sci 106:5-28

27. Hunt PR (2017) The C. elegans model in toxicity testing. J Appl Toxicol 37:50-59

28. Sifri CD, Begun J, Ausubel FM, Calderwood SB (2003) Caenorhabditis elegans as a model host for Staphylococcus aureus pathogenesis. Infect Immun 71:2208-2217

29. Diard M, Baeriswyl S, Clermont O, Gouriou S, Picard B, Taddei F, Denamur E, Matic I (2007) Caenorhabditis elegans as a simple model to study phenotypic and genetic virulence determinants of extraintestinal pathogenic Escherichia coli. Microbes Infect 9:214-223

30. Son S, Park M, Ryu S, Maburutse B, Oh N, Park J, Oh S, Kim Y (2016) In vivo screening plat form for bacteriocins using 
Caenorhabditis elegans to control mastitis-causing pathogens. J Dairy Sci 99:8614-8621

31. Yun B, Jang YJ, Kim YR, Kim H-Y, Kim W-I, Han S, Kim S-R, Ryu S-G, Kim H-J (2017) Virulence profile and antimicrobial resistance of Escherichia coli from flies captured from agricultural environment. J Food Hyg Saf 32:147-153

32. Kim Y, Mylonakis E (2012) Caenorhabditis elegans immune conditioning with the probiotic bacterium Lactobacillus acidophilus strain NCFM enhances gram-positive immune responses. Infect Immun 80:2500-2508

33. Brenner S (1974) The genetics of Caenorhabditis elegans. Genetics 77:71-94

34. Lee JK, Jung DW, Kim YJ, Cha SK, Lee MK, Ahn BH, Kwak NS, Oh SW (2009) Growth inhibitory effect of fermented kimchi on food-borne pathogens. Food Sci Biotechnol 18:12-17

35. Pagadala S, Marine SC, Micallef SA, Wang F, Pahl DM, Melendez MV, Kline WL, Oni RA, Walsh CS, Everts KL, Buchanan RL (2015) Assessment of region, farming system, irrigation source and sampling time as food safety risk factors for tomatoes. Int J Food Microbiol 196:98-108

36. US Food and Drug Administration (2017) FSMA final rule on produce safety. Standards for the growing, harvesting, packing, and holding of produce for human consumption

37. Sayah RS, Kaneene JB, Johnson Y, Miller R (2005) Patterns of antimicrobial resistance observed in Escherichia coli isolates obtained from domestic-and wild-animal fecal samples, human septage, and surface water. Appl Environ Microbiol 71:1394-1404

38. Chigor VN, Umoh VJ, Smith SI, Igbinosa EO, Okoh AI (2010) Multidrug resistance and plasmid patterns of Escherichia coli O157 and other $E$. coli isolated from diarrhoeal stools and surface waters from some selected sources in Zaria, Nigeria. Int J Environ Res Public Health 7:3831-3841

39. Talukdar PK, Rahman M, Rahman M, Nabi A, Islam Z, Hoque MM, Endtz HP, Islam MA (2013) Antimicrobial resistance, virulence factors and genetic diversity of Escherichia coli isolates from household water supply in Dhaka, Bangladesh. PLoS ONE 8:e61090

40. Lim S, Lee H, Byun J, Park S, Jung S (2007) Antimicrobial resistance of commensal bacteria isolated from food-producing animals I. Antimicrobial resistance of Escherichia coli and Enterococcus spp. isolated from cattle faecal samples. Korean J Vet Public Health 31:21-29

41. Kim A, Cho Y, Lim S, Her M, Jeong W, Jung S, Kown J (2007) Antimicrobial resistance of commensal bacteria isolated from food-producing animals III. Antimicrobial resistance of Escherichia coli and Enterococcus spp. isolated from chicken faecal samples. Korean J Vet Public Health 31:4-49

42. Jeong KO, Heo JH, Lee JM, Yun IR, Choi YJ, Kim JS (2010) Surveillance of antimicrobial resistance ratio of E. coli and Enterococcus spp. isolated from fecal and carcasses of pigs in slaughterhouse. Korean J Vet Serv 33:241-248

43. Lee JI, Han GY, Park HH (2003) Characteristics and antibiotics susceptibility of Escherichia coli isolated from fishery products. Korean J Food Nutr 16:111-115

44. Oh H, Park J (2009) Characteristics of antibiotic resistant bacteria in urban sewage and river. J Korean Soc Environ Eng 31:232-239

45. Cho JI, Joo IS, Park KS, Han MK, Son NR, Jeong SJ, Heo J, Kim YJ, Oh MH, Kim SH, Lee SH (2014) Characterization of pathogenic Escherichia coli strains linked to an outbreak associated with kimchi consumption in South Korea, 2012. Food Sci Biotechnol 23:209-214

46. Merkx-Jacques A, Coors A, Brousseau R, Masson L, Mazza A, Tien Y-C, Topp E (2013) Evaluating the pathogenic potential of environmental Escherichia coli by using the Caenorhabditis elegans infection model. Appl Environ Microbiol 79:2435-2445

47. Canada Health (2000) Waterborne outbreak of gastroenteritis associated with a contaminated municipal water supply, Walkerton, Ontario, May-June 2000. Can Commun Dis Rep 26:170-173

48. Greig J, Rajic A, Yong I, Mascarenhas M, Waddell L, Lejeune J (2015) A scoping review of the role of wildlife in the transmission of bacterial pathogens and antimicrobial resistance to the food chain. Zoonoses Public Health 62:269-284

49. Allende A, Monaghan J (2015) Irrigation water quality for leafy crops: a perspective of risks and potential solutions. Int J Environ Res Public Health 12:7457-7477 